JISTE, Vol. 25, No. 1, 2021

\title{
Reflections on place, Place-Based Education and Wild Pedagogies in Denmark: A Schooner Project
}

\author{
Karen Bjerg Petersen \\ Danish School of Education, Aarhus University, Denmark
}

\begin{abstract}
Based on philosophical reflections on the concepts of place, place-based education, wild pedagogies and outdoor schooling in Denmark, the article presents and reflects upon selected results from a three-year accompanying qualitative research conducted in connection with a project for underserved young people and students. Approximately 40 participants aged 14-29 with social, personal, relational and/or substance abuse problems were enrolled as crewmembers on a schooner in periods ranging from a few weeks to six to eight months during the project's three-year duration. The results indicate that place, nature, an extended stay and the relationship competency of the crew are all factors that can have a positive and transformative impact on participants, supporting their efforts to get "on an even keel" - to use a maritime expression that alludes to keeping a vessel's keel steady, assuring smooth sailing.
\end{abstract}

Keywords: place-based education, wild pedagogy, underserved students, well-being, alternative pedagogy

\section{Introduction}

On March 15, 2021, a class of Danish grade seven students met with their biology teacher outside the Planetarium, located by the lakes in Copenhagen, for their face-to-face lesson in many months (Jensen, 2021). Like schoolchildren in many European countries, Danish students in grades five to nine have been taught online, unable to attend school. Even as some of the restrictions were lifted, the class was not allowed to meet in the classroom. Due to local Covid-19 restrictions, students in grades 5-12 in the Copenhagen area were only allowed to meet in person once a week, and only outdoors. One young student, who had previously enjoyed having days off in school, expressed her joy at being back at school, "in the beginning, it felt so great that we did not have to go to school. Now, I am so happy that we are allowed to go back" (Jensen, 2021).

With respect to the teaching content of this particular outdoor school day in Copenhagen, the biology teacher emphasized, that 'this day is about so much more than photosynthesis and bird species. The students must be given time to find each other as a group again'. 
Photos showing students talking and walking in pairs around the Copenhagen lakes clearly show that this first day back took place at a very different location or "place" than usual, schools generally being associated with buildings, classrooms, institutions.

The above account reveals many things about how the Covid-19 pandemic has affected all aspects of personal and societal life for the past year in many countries. Schools in Denmark have been closed for months, online teaching is "the new normal," and many schoolchildren are forced to stay at home with no or very little contact with classmates and friends. Many aspects of the pandemic's impact on teaching and learning are already being studied. Inspired by the unusual environment of the outdoor teaching day in Copenhagen, however, this article will reflect on the implications of "place" for education.

The American philosopher Edward S. Casey (1997; 2001, 2009) has reflected on the concept of place from a philosophical perspective, and the Austrian-Canadian researcher David Greenwood has developed the so-called "place-based education" approach (Greenwood \& Smith, 2014). Jickling, Blenkinsop, Timmerman, \& Sitka-Sage (2018) introduced the idea of "wild pedagogies," which takes nature seriously as an important part of education, and, in Denmark, "outdoor schools," "nature schools" and various nature-based projects were developed during the 2010s - not only for mainstream schools, but also in projects focusing on underserved students (Knudsen, 2020; Petersen \& Andersen, 2021). Thus, "place" as a notion, a site and a location plays a pivotal role in education, even if not always at the center of educational research.

In this article, I will introduce and reflect upon the concepts of place, place-based education, and wild pedagogies. Drawing on an accompanying research on underserved young people's participation in a Danish three-year "place-based" project on a schooner, I will discuss some of the results in relation to the notions of place-based learning and wild pedagogies. Finally, I will return to the current situation in Denmark during the Covid-19 pandemic and reflect on the possibilities for richer education, even in a situation with enforced outdoor schooling like the school day in Copenhagen on March 15, 2021.

\section{Place, place-based education, wild pedagogies and open schools}

Theoretical and philosophical reflections on the concept of "place," often as opposed to "space" (Casey, 2009), are cornerstones of not only the approach of "place-based education" (Greenwood \& Smith, 2014), but also that of "wild pedagogies" (Jickling et al., 2018).

The notion of "place"

The American philosopher Casey $(1997 ; 2001 ; 2009)$ has discussed and elaborated on the concept of "place." In an early article from 1997, he poses a central question - and implicit 
hypothesis - about place: "Or might it be so that place is something special, with its own essential structures and modes of experience, even something universal in its own way?" (Casey, 1997, p. 13). Casey (2009) elaborates on this hypothesis in his later work, emphasizing the importance of perceiving "place" - be it different sites, locations or emplacements - as a phenomenon in itself. In an article from 2001, Casey defines "place" as "the immediate environment of my lived body - an arena of action that is at once physical and historical, social and cultural" (p. 683). CruzPierre \& Landes (2013) highlight Casey's emphasis on place as the environment of a person's lived body, which adds an anthropological connotation to his understanding of place because "“an unplaced' or 'disembodied' memory is impossible”. In Getting Back to Place (2009), Casey focuses on the importance of place - as opposed to space - for individuals and their memories, histories and even their psychological well-being. He writes,

I shall accord to place a position of renewed respect by specifying its power to direct and stabilize us, to memorialize and identify us, to tell us who and what we are in terms of where we are (as well as where we are not) (p. xv).

As mentioned by Cruz-Pieere and Landes (2013), Casey puts forward

a renewed understanding of the place-world. The placial and bodily aspects of memory invite a phenomenological description of 'embodied implacement', and phenomenology becomes an exploration of the body in built and wild places. Human experience, then, is the ongoing journey between places. (p.3).

\section{Place-based education}

While Casey foregrounds the concept and importance of place from a philosophical perspective, Greenwood and colleagues, in their efforts to introduce a new approach to education, take the notion of place further by introducing the concept of "place-based education" (Greenwood, 2013, 2013a, 2019; Greenwood \& Smith, 2014). In Place-based education in the global age: local diversity, Greenwood \& Smith (2014) suggest that educational institutions overlook the fact that every human being exists in a place that surrounds and co-creates not only the individual, but also the institution and society. In addition, they argue - hereby in many ways echoing Casey's connotation of the notion of place - that basing educational institutions in places rather than in abstract systems entails viewing students as real, living and breathing (embodied) persons for whom teaching has tangible effect. The critique raised by researchers is hence that educational institutions have become abstract entities deprived of contact with the real world. Smith (2002) emphasizes as one of the strengths of a place-based approach to education that it "can adapt to the unique characteristics of particular places, and in this way it can help overcome the disjuncture between school and children's lives that is found in too many classrooms" (p.584). 
He underlines that, "although educators are often quick to say that schools are as much the 'real world' as any place else, ... what happens in classrooms is qualitatively different from what happens elsewhere" (p.586). In school, Smith continues, the real world is mediated, and "the job of students - despite all the well-intentioned attempts to engage them as participants in the construction of meaning — is to internalize and master knowledge created by others" (p.586).

Quoting the American educationalist John Dewey, Smith (2002) points to an epistemological aspect of place-based education for children,

From the standpoint of the child, the great waste in the school comes from their inability to utilize the experiences they get outside the school in any complete and free way within the school itself; while, on the other hand, they are unable to apply in daily life what they are learning at school (p. 585).

Place-based education hence strives to position children as central actors in their own lives and learning - among other things, by taking them to different places and facilitating different experiences, or by involving them in activities addressing real-world problems. Smith (2002) points to three different variations of place-based education: cultural studies, e.g. "oral histories and journalism" (p. 588), nature studies, e.g. "investigation of local natural phenomena and nature" (p. 588) and real-world problem-solving, e.g. "engaging students in the identification of school or community issues that they would like to investigate and address" (p. 589). In many ways, the recently introduced concept of "wild pedagogies" can be seen as a new kind of nature studies approach.

Wild pedagogies

In the book Wild pedagogies: touchstones for re-negotiating education and the environment in the Anthropocene, the authors propose a new pedagogy, partly as a critique of and solution to the so-called Anthropocene era, characterized by the significant human impact on Earth's geology and ecosystem, including but not limited to climate change (Jickling et al., 2018). According to the authors, "Wild pedagogies aims to re-examine relationships with places, landscapes, nature, more-than-human beings, and the wild" (p. 1). As such, like the work of Casey (2009) and Greenwood \& Smith (2014), wild pedagogies focus on places and, in particular, on nature as the focus of a re-negotiation of education.

Jickling et al. (2018) furthermore introduce several touchstones or creeds while outlining their understanding of how education should be re-negotiated. In the first of these touchstones, they suggest nature be treated as a co-teacher in education:

\#1: We believe that education is richer, for all involved, if the natural world and the many denizens that co-constitute places, are actively engaged with, listened to, and taken 
seriously as part of the educative process (p. 80).

Similar to the founders of place-based education, emphasizing the necessity to focus on real-world issues and introduce and engage students in learning, in their second touchstone, the founders of wild pedagogies claim "that education is richer for all involved, if there is room left for surprise" (p. 84). However, "wild pedagogies" are not understood as only taking place in nature per se. Like Casey's (2009) complex notion of place, in their third touchstone Jickling et al. (2018) emphasize:

\#3: We believe that the wild can be found everywhere, but that this recognition and the work of finding the wild is not necessarily easy. The wild can be occluded, made hard to see, by cultural tools, by the colonial orientation of those doing the encountering, and, in urban spaces, by concrete itself (p. 88).

According to Jickling et al. (2018), wild pedagogies thus strive to raise students' awareness of and active engagement in places, whether located in natural or urban environments, by encouraging both students and teachers to listen to nature and places and take them seriously "as part of the educative process" (p. 80). A growing interest in increasing students' awareness of place, be it in the shape of specific approaches such as place-based education and wild pedagogies or general efforts to engage schoolchildren in their location and 'embodied' real-word while learning, has also been evident in Denmark since the 2010s.

Open schools in Denmark in the 2010s

In the 2010s, a new concept of so-called "open schools" - seeking to nurture students' engagement in and sense of responsibility for their local communities and natural surroundings was introduced in Danish primary and lower secondary schools (Danish: Folkeskole). The Danish Folkeskole Act from 2014 established a statutory foundation for open schools (LBK no. 665 of 20/06/2014, chapter 2, subsection 4), obliging schools to enter into partnership agreements with local organizations (Knudsen, 2020). Outdoor teaching initiatives in Denmark, such as outdoor schools, museum pedagogies, nature schools, and open schools, challenge the usual physical and organizational framework for teaching (Hartmeyer, Bølling \& Bentsen, 2017). Research on outdoor school education has focused on the importance of learning about scientific phenomena in natural milieus, and on how student wellbeing and teaching are affected when lessons move outside. Danish researchers have found added value in local partnerships, and in the concepts of open schools and outdoor schooling, claiming that open and outdoor schooling principles add an extra dimension to traditional schooling and support students' development of creative and democratic competencies (Knudsen, 2020; Rosenbäck \& Knudsen, 2020). However, a placebased educational approach, such as that developed by Greenwood and Smith (2014), has been absent from the Danish research. In the following, I will introduce a three-year "place-based" 
project that sought to support underserved Danish young people and students.

\section{A Danish "place-based project" for underserved young people and students}

As in many other European countries (European Commission, 2014), a certain percentage of young people in Denmark leave school without qualifications (Vive, 2019). This group (often labeled dropouts) - who, for various reasons, do not succeed in finishing school, which in a Danish context means competing grade 9 or grade 10 - has been a concern not only for schools, teachers and politicians, but also for the local communities where the young people live. After leaving school, some of these young people become involved in criminal activities, such as gang violence and substance abuse, and/or experience psychological and even physical illness due to poor nutrition (Vive, 2019). Well-being is often an unknown concept for these young people.

Being known for its relatively large port and shipping activities, a city municipality located at the west cost of Denmark finds that many of its young residents leave school too early. The local authorities contacted the crew of an old schooner located in the city port, known for working with socially disadvantaged young people from all over the country. A three-year contract was agreed in which the crew of the schooner undertook to host vulnerable young people from the municipality. In addition, it was decided to establish a three-year accompanying research project following the young people enrolled on the schooner. The author of this article and a colleague carried out this follow-up research (Petersen \& Andersen, 2021). In the following, I present the schooner project and its target group, as well as the methodology of the research and selected results.

\section{Target group}

The municipality set a number of criteria for the target group. The young people (aged 14 to 29) to be enrolled on the schooner were defined as needing "new experiences" and to be "part of meaningful communities." They struggled with a lack of self-esteem, self-confidence and wellbeing and were in need of a more clearly structured rhythm to help them organize their everyday lives. Furthermore, the project was targeted at young people with personal, emotional or/and social difficulties and who struggled with establishing and maintaining interpersonal relationships. They lacked motivation concerning their own educational and career opportunities, most of them labeled dropouts. They had often been diagnosed with various psychiatric or other medical conditions and some of them struggled with substance abuse problems. Finally, the project targeted young people who needed a change of scenery due to their particular circumstances, whether of a social, cultural, personal or financial nature. In sum, the target group was underserved young people and students facing extensive family, social, educational, substance abuse and/ or 
other problems (Petersen \& Andersen, 2021). In continuation of Nielsen (2011, 2013), Dam \& Siang (2021) defining "persona" as "fictional characters" that are created "based upon [...] research" in order to represent a typical person (n.p.) - the following persona description illustrates a typical young participant on the schooner.

\section{Persona}

Johan is 20 years old and on state benefits. He has attended several youth education programs, but never finished any of them. He now spends most of his waking hours sitting at home in his apartment in front of either the television or computer. He has been assigned a social worker who tries to help him figure out what to do with his life. He also has a drug addiction and the only exercise he gets is when going to the shops. Johan states that he feels tired and unwell and his mood is not the best either.

Socially, he states that he has no relationships with other people and that he has cut ties with most of his family. He feels lonely and has difficulty in finding friends. He has no plans for the future in terms of jobs or education. He wants to become clean, but struggles with that too. He does not know what to do, but would like to somehow get away from his current life (Petersen \& Andersen, 2021, p. 17).

\section{The schooner project}

Once enrolled, the young people become part of the schooner's crew as sailors. They must be part of the everyday life and work on the schooner. Each sailor has an individual action plan adapted to his/her abilities and needs. The overall goal is to give the young people positive experiences and a sense of achievement so that they can regain a belief in themselves and develop the courage to make plans for the future.

There is room on board for four young people at a time, alongside the schooner's three full-time employees. Usually, the young people sail with the schooner for three weeks, after which they have one week off on land. Young people are typically enrolled on the schooner for a period of three months; however, the period varies for each young person, from a few weeks to several months. The schooner has many visitors all year round and therefore often sails with guests. For example, many school classes organize in school trips, spending a night or more on the schooner. During these visits, the young sailors (the enrolled disadvantaged young people) are given various responsibilities and tasks. Otherwise, there are only few requirements that the young people must meet during the course of a day: They must attend meals and help with the dishes every day, as well as being given various individual tasks on the schooner.

During the project's three-year duration, approximately 40 young people were enrolled on the schooner, most of them boys with approximately $10 \%$ girls (Petersen \& Andersen, 2021). 


\section{Methodology}

The qualitative accompanying research during the three-year period was based on a case study approach, field observations on the schooner and interviews with participating young people and the schooner's crew.

Qualitative interviews were carried out with the participants before and during their stay on the schooner, with participants enrolled during the first two years also interviewed after their stay. During year three of the project, the municipality started sending young people aged 14-16 from special needs schools. These participants - who also met the aforementioned criteria - were only enrolled on the schooner for shorter periods and were only interviewed during their stay.

Yin (2003) defines a case study as "an empirical inquiry that investigates a contemporary phenomenon within its real-life context, especially when the boundaries between phenomenon and context are not clearly evident" (p. 13). Field observations were conducted with the aim of understanding, interacting with and observing participants in their everyday surroundings during their stay on the schooner. Qualitative interviews are useful when collecting data about specific people's experiences, beliefs and social contexts. They provide an opportunity to examine how individuals understand specific events and situations in their lives (Brinkmann \& Tanggaard, 2015, p. 32).

The data from the observations and qualitative interviews were transcribed and hereafter coded and condensed. As outlined by Brinkmann \& Tanggaard (2015), condensing refers to the process of selecting, focusing and abstracting data into smaller units for analytical purposes. Malterud (2012) describes the analytical process as follows,

The procedure consists of the following steps: 1) total impression - from chaos to themes;

2) identifying and sorting meaning units - from themes to codes; 3) condensation - from code to meaning; 4) synthesizing - from condensation to descriptions and concepts ( $\mathrm{p}$. 795).

In addition, a Strengths and Difficulties Questionnaire (SDQ) was applied as "a brief behavioural screening questionnaire," aimed at identifying "emotional symptoms; conduct problems; hyperactivity/inattention; peer relationship problems; and prosocial behaviour" (SDQ, 2021).

\section{Selected results}

As mentioned in the introduction of the "persona" description, the participants in the schooner project had all experienced personal, social, behavioral, emotional and/or substance 
abuse problems prior to the project. The compiled data indicate that they all benefitted from their stay on the schooner; however, they did not all succeed in changing their situation and hereby getting themselves "on an even keel" - to use a maritime expression that alludes to keeping a vessel's keel steady, assuring smooth sailing. Some of the results are presented below.

The importance of nature and "place"

When asked what particularly impressed the participants during their stay on the schooner, many of them mentioned the schooner itself and being close to nature around the clock.

One participant expressed the importance of place and nature as follows

So it's just: waking up in fresh air by the sea at sunrise, and we are [...] always in really nice places with really beautiful nature and the like, $[\ldots]$ and it gives you energy and extra motivation to get up, even at seven in the morning [...] it's damn hard to be negative and tired, I guess (Petersen \& Andersen, 2021)

Another participant emphasized the natural environment in a similar way, saying "there is beautiful nature and fresh air." A third participant told us, "I like being out at sea, and the things you learn and stuff like that, it's really cool."

Some of the participants emphasized nature's calming and even psychologically positive influence on them. One participant explained that the stay on the schooner gave her "peace." Another - mentioning her highly tumultuous life 'on land' - described what happened to her while staying on the ship and in nature:

I can breathe and I can give my head and my brain some space here on the schooner (Petersen \& Andersen, 2021).

The particular setting of the schooner, sailing in different waters and always in nature, thus influenced the participants in various ways. In many ways, the young people's statements mirror Casey's (2009) emphasis on the power of place as able "to direct and stabilize us, to memorialize and identify us, to tell us who and what we are in terms of where we are (as well as where we are not)" (p. xv). The schooner, as a place diametrically opposed to their home environment (where they were not), had a stabilizing influence on the participants. Jickling et al.'s (2018) belief "that education is richer, for all involved, if the natural world and the many denizens that coconstitute places, are actively engaged with, listened to, and taken seriously as part of the educative process" (p. 80) can likewise be said to characterize the special place-based education provided at sea on the schooner.

Longer stays on the schooner tend to be more effective in getting the participants "on an even keel"

A further finding of the project was that the longer the duration of the young people's stay 
on the schooner, the greater the likelihood that they - particularly those over the age of 18 - were able to free themselves from previous drug addiction, poor family relationships and low selfesteem. When interviewed again towards the end of the project, three of the participants who had been enrolled on the schooner for more than six months during the project's first year were now enrolled in a maritime educational program and had sailed and worked on other ships after their stay on the schooner. A further participant, who was interviewed several times (at the beginning, in the middle and at the end of his six-month stay on the schooner), underwent a major personal development. Having had no relationship with his sisters or parents for years - due to long-term substance abuse - this young person kicked his habit while on the schooner and started seeing his parents again, and eventually his sister, whom he had not seen for six years. "It took a real leap of faith to contact her" as he explained in one of the last interviews. After the interview, the captain told the interviewer that the sister was now a great "fan" of the schooner (Petersen \& Andersen, 2021).

By contrast, the interviews indicated that shorter stays on the schooner tended to result in less profound changes for participants. Some of these students perceived the stay more as "entertainment," albeit a positive experience. The results thus indicate that brief changes in circumstances tend to have only short-term effects.

Participants' relationships with the crew and the captain are crucial

Another factor mentioned by the participants was their relationships with the crew and the captain, with all of them highlighting the crew, including the captain and his personality and behavior, as crucial to their stay. Some of the young people's statements are evidence of this: "he talks to us as adults and equals," "he laughs with us and teases us a bit sometimes," and "he is always in a good mood." One participant recounted talking with the captain during a four-hour shift, stating that he was not used to having such conversations at home. Klinge (2017) and others (Polite \& Burgh, 1992) have stressed the importance of the teacher's so-called relationship competency, defined as the ability to establish good teaching and learning environments and positive relationships with students. Similarly, Klinge (2017) describes a teacher's relationship competency as the ability to establish a positive relationship with each individual student and with the class as a whole. Such relational competency promotes students' well-being and all-round professional, social and personal development. In interviews, the captain indicated that he was well aware of his role as a 'teacher' in the particular place-based educational setting of the schooner. The interviews with participating young people showed that he and the rest of the crew generally demonstrated "relationship competency".

In summary, the specific place and approach to place-based education within nature on the 
schooner, the duration of the stay and the relationship competency of the crew stand out as three important themes in the analysis of the results.

\section{Concluding reflections on possibilities for developing richer education as a result of the pandemic}

To a great extent, the Danish project for underserved and disadvantaged students and dropouts described in this article reflects intentions found in approaches like place-based education and wild pedagogies and mirrors the philosophical approach to "place" described by Casey. "Place" - with "its own essential structures and modes of experience, even something universal in its own way" (Casey, 1997, p.13) - is particularly clear and relevant in this project. The schooner is itself a physical place with its own structures and providing various modes of experience, while at the same time moving around between different places as it sails around in different waters along the Danish coastline.

The project furthermore reflects a place-based education approach. Just as Greenwood and Smith (2014) emphasize that children and students must be central actors in their own lives and that they should learn by being taken to specific places and through their involvement in real-life activities, the schooner project offered participants a range of real-world experiences.

The importance of nature - emphasized in the wild pedagogies approach - is likewise an obvious and central aspect of the project. The results from the accompanying research indicate that the real-world education provided on the schooner in many ways seems to be "richer, for all involved" because "the natural world" of the sea co-constituted places in which the participants were "actively engaged with, listened to." As such, nature and place were taken "seriously" as "part of the educative process" (Jickling et al., 2018, p. 80).

Although highly atypical in terms of a traditional understanding of education as something that takes place in formalized institutions and buildings, and despite the fact that the results may not be transferable to teaching and learning in mainstream schools, the schooner project and approaches such as place-based education and wild pedagogies offer interesting reflections and inspiration in the form of alternative ways of rethinking education. All over the world, including the Scandinavian countries, much mainstream education has been criticized for focusing on tests and assessment rather than on the students (Dovemark et al., 2018; Imsen, Blossing \& Moos, 2017) and their unique qualities (Biesta, 2011). There is thus a need to explore ways of developing "richer education" centered on the students rather than curricula, tests and assessments.

To return to the episode described in the introduction to this article, Covid-19 has also changed traditional conceptions of schools and the school environment and 'taken-for-granted' 
locations. As the biology teacher emphasized, the outdoor lesson in Copenhagen was not only about photosynthesis and wildlife. This teacher is aware that many other factors - including a focus on socializing and students' well-being - are of paramount importance for teaching and learning.

Covid-19 might hereby open the eyes of teachers, students and educators across the world to new ways of developing "richer education." Focusing on places, nature, place-based education and wild pedagogies may contribute to such reflections.

\section{References}

Brinkmann, S., \& Tanggaard, L. (2015). Kvalitative metoder - en grundbog. København: Hans Reitzels Forlag.

Casey, E. S. (1997) How to get from space to place in a fairly short stretch of time: Phenomenological prolegomena, in S. Feld \& K. Basso (Eds.) Senses of Place. School of American Research Press.

Casey, E. S. (2001). Between geography and philosophy: What does it mean to be in the placeworld? Annals of the Association of American Geographers, 91(4), 683-693.

Casey, E. S. (2009). Getting back into place: Toward a renewed understanding of the place-world. Bloomington: Indiana University Press.

Cruz-Pierre, A., \& D. A. Landes (Eds.) (2013). Exploring the work of Edward S. Casey: Giving voice to place, memory, and imagination. Bloomsbury Academic.

Dam, R.F., \& T. Y. Siang (2021). Personas - A simple introduction. Retrieved from https://www.interaction-design.org/literature/article/personas-why-and-how-you-shoulduse-them

Dovemark, M., Kosunen, S., Kauko, J., Magnasdottir, B., Hansen, P., \& Rasmussen, P. (2018). Deregulation, privatisation and marketisation of Nordic comprehensive education: social changes reflected in schooling, Education Inquiry, 9(1), 122-141, DOI: $10.1080 / 20004508.2018 .1429768$

European Commission (2014). Study on the effective use of early childhood education and care $(E C E C)$ in preventing early school leaving (ESL). Final report. Publications Office of the EU. Retrieved from: https://op.europa.eu/en/publication-detail/-/publication/7548dd37c626-4e2d-bd70-625edf707adc/language-en/format-PDF/source-search

Greenwood, D. (2013). What is outside of outdoor education? Becoming responsive to other places. Educational Studies, 451-464. https://doi.org/10.1080/00131946.2013.825261

Greenwood, D. A. (2013a). A critical theory of place-conscious education. In R. B. Stevenson, 
M. Brody, J. Dillon, \& A. E. J. Wals (Eds.), International handbook of research on environmental education, (pp. 93-100). New York, NY: Routledge.

Greenwood, D. (2016). Creative tensions in place-conscious learning: A triptych. Journal of the Canadian Association for Curriculum Studies (JCACS) 13(2).

Greenwood, D. \& G. Smith (2014). Place-based education in the global age: local diversity. Lawrence Erlbaum.

Hartmeyer, R., Bølling, M., \& Bentsen, P., (2017). Approaching multidimensional forms of knowledge through personal meaning: Mapping in science integrating teaching outside the classroom. Instructional Science, 45(6), 737-750.

Imsen, G., Blossing, U., \& Moos, L. (2017) Reshaping the Nordic education model in an era of efficiency: Changes in the comprehensive school project in Denmark, Norway, and Sweden since the millennium. Scandinavian Journal of Educational Research, 61(5), 568583, DOI: 10.1080/00313831.2016.1172502

Jensen, M. T. (2021). Elever i hele landet fik i dag lov til at komme tilbage i skle - men for disse var det en kort fornøjelse. Retrieved from https://nyheder.tv2.dk/samfund/2021-03-15elever-i-hele-landet-fik-i-dag-lov-at-komme-tilbage-i-skole-men-for-disse-var-det

Jickling, B., Blenkinsop, S., Timmerman, N., \& Sitka-Sage, M. (2019). Wild pedagogies: Touchstones for re-negotiating education and the environment in the Anthropocene. Palgrave MacMillan.

Klinge, L. (2017). Laereres relationskompetence. kendetegn, betingelser og perspektiverl [Relationship competency of teachers. Characteristics, conditions and perspectives]. Dafolo.

Knudsen, L.E.D. (2020). Introduktion: om baggrund, bredde og sammenhænge i åben skole. I L.E.D.Knudsen, L.L. Jensen, A.V. Thomsen \& M. Fredslund (Eds.), Åben Skole. (pp. 925). Syddansk Universitetsforlag,

Malterud, K. (2012). Systematic text condensation: A strategy for qualitative analysis. Scandinavian Journal of Public Health, 40(8), 795-805 https://doi.org/10.1177/1403494812465030

Nielsen, K. (2011). Behaviorisme og social-kognitiv læringsteori. I B. Karpatschof, S. Hart, S. Chaiklin, \& m.fl., Klassisk og moderne psykologisk teori (s. 260-264). København: Hans Reitzels Forlag.

Nielsen, L. (2013). Personas. In M. Soegaard, \& R. F, Dam (Eds.). The encyclopedia of humancomputer interaction, (2nd ed.) The Interaction Design Foundation. https://www.interaction-design.org/encyclopedia/personas.html 
Petersen, K. B. \& Andersen, F.Ø. (2021, forthcoming). Fulton projektet. Forskningsrapport. [The Fulton project. Research report]. Aarhus Universitet.

Polite, K., \& Bourg, E. (1992). Relationship competency. In R. L. Peterson, J. D. McHolland, R. J. Bent, E. Davis-Russell, G. E. Edwall, K. Polite, D. L. Singer, \& G. Stricker (Eds.), The core curriculum in professional psychology (pp. 83-88). American Psychological Association. https://doi.org/10.1037/10103-009

Rosenbäck, I. S. \& Knudsen, L. E. D. (2020). Pædagogik og partnerskaber - et litteraturreview om samarbejder mellem skoler og lokalsamfund. I: Lars Emmerik Damgaard Knudsen, Laura Lundager, Mette Fredslund \& Anders Vestergaard Thomsen (red.), Åben skole. Syddansk Universitetsforlag.

Smith, G.A. (2002) Place-based Education learning to be where we are, Phi Delta Kappan 83(8), 584-594. Retrieved from https://journals.sagepub.com/doi/pdf/10.1177/003172170208300806

Vive. (2019). Unge uden job og uddannelse - hvor mange, hvorfra, hvorhen og hvorfor? København: Det Nationale Forsknings- og Analysecenter for Velfærd. Retrieved from https://www.vive.dk/media/pure/14561/3641625

Yin, K. R. (2003). Case study research. Sage Publications, Inc.

\section{Author}

Karen Bjerg Petersen is an Associate Professor at the Danish School of Education at Aarhus University, Denmark. Her research areas are alternative educational settings, diversity, vulnerable youth and informal learning. She is the editor of JISTE - Journal of the International Society for Teacher Education. 